\title{
KARATERISTIK DENDENG IKAN NILA (Oreochromis niloticus) DENGAN KONSENTRASI PENAMBAHAN GULA AREN BERBEDA
}

\author{
The Carateristic Of Nile Tilapia Fish (Oreochromis niloticus) \\ Jerky With The Addition Of Palm Sugar At Different \\ Harnisah $^{1}$, Slamet Riyadi ${ }^{2}$, dan Fitra Mulia Jaya ${ }^{2}$ \\ ${ }^{1}$ Alumni Fakultas Perikanan Universitas PGRI Palembang \\ ${ }^{2}$ Staf Pengajar Fakultas Perikanan Universitas PGRI Palembang
}

\begin{abstract}
Abstrak
Ikan merupakan sumber bahan pangan yang bermutu tinggi terutama karena ikan banyak mengandung protein, lemak, vitamin dan mineral yang sanggat dibutuhkan oleh manusia. Untuk mendapatkan nilai tambah dari ikan Nila maka perlu dilakukan diversifikasi pengolahan untuk menciptakan produk baru serta memperpanjang daya awet ikan. Salah satu diversifikasi pengolahan adalah pengolahan dendeng ikan. Komposisi bahan baku dan pencampuran bumbu-bumbu dalam pengolahan produk dendeng akan mempengaruhi kualitas dendeng yang dihasilkan. Salah satunya yaitu gula merah, gula merah adalah zat senyawa organik yang dapat mengikat air, memodifikasi rasa, warna, tekstur dan memperlambat pertumbuhan mikroba. Penelitian ini bertujuan untuk mengetahui karateristik dendeng Ikan Nila dengan penambahan konsentrasi gula aren berbeda.Penelitian ini dilaksanakan pada bulan Juni-Agustus 2013 yang dilaksanakan di Laboratorium Kimia Hasil Pertanian (LKHP) Jurusan Teknologi Hasil Pertanian Universitas Sriwijaya Indralaya, dengan mengunakan Rancangan Acak Lengkap (RAL) yang diulang sebanyak tiga kali ulangan. Hasil penelitian menunjukan perlakuan penambahan konsentrasi gula aren berbeda, berpengaruh nyata terhadap tekstur, lightness, chroma, hue, kadar air, kadar abu, kadar lemak, kadar protein dan karbohidrat. Perlakuan terbaik terdapat pada perlakuan G3 (penambahan gula 30\%) dengan farameter fisik (tekstur 872,03 gf, lightness 35,33, chroma 6,80 dan hue 60,30), farameter kimia (kadar air 15,56\%, kadar abu 4,32\%, kadar lemak 14,36\%, kadar protein 26,67\% dan karbohidrat 38,04\%), dan sensoris (penampakan 3,92\%, aroma 4,00\%, warna 3,92\% dan rasa 4,24\%).
\end{abstract}

Kata kunci: Dendeng, Ikan nila, Gula aren

\begin{abstract}
Fish is source of animal food in high quality mainly go to because fish contains protein, fats, vitamin and minerals that are needed by human. The diversification of nile tilafia fish processing product is needed to creat the new product and to extend the fish shelf life such as fish jerky. The ingredients composition will affected the quality of fish jerky. Palm sugar as ingredients of jerky processing will bridly water. Modification of taste, cown, texture and texture rate of microbe growth. The objective of the research is to study the characteristic of nile tilapia jerky with addition of palm sugar at different concentrations. The result has done us June-Augustus 2013, which was conducted in the laboratory of agri cull total chemical (LKHP) majoring in agricultural technology agricultural University Faculty Sriwijaya Indaralaya using a compelety randomized design is repeated 3 time repetition. The result is shows the treatmen of addition of palm sugar at different concentrasion is significant effect on (texture 872,03 gf, lightess 35,33, chroma 6,80 , hue 60,30) with parameter chemical (water content 15,56\%, ash content 4,32\%, fat content 14,36\%, protein conten $27,67 \%$ and carbohydrate 36,00) and sensoris (aperance of 3,92\%, aroma 4,00\%, color $3,92 \%$ and flavor $4,24 \%)$.
\end{abstract}

Keywords: Jerky, Nile tilapia fish, Palm sugar 


\section{PENDAHULUAN}

Sumatera Selatan adalah salah satu wilayah Indonesia yang kaya akan potensi perikanan air tawarnya. Berbagai komoditas perairan tawar yang dihasilkan berasal dari sungai, danau dan rawa meliputi : ikan, udang, dan hewan moluska. Diantara jenis-jenis ikan air tawar yang sekarang sedang dikembangkan dan dibudidayakan adalah ikan Nila (Heriansyah, 2010).

Ikan merupakan sumber bahan pangan yang bermutu tinggi, terutama karena ikan banyak mengandung protein, lemak, vitamin dan mineral yang sangat dibutuhkan oleh tubuh manusia. Daging ikan pada umumnya mengandung air antara $64-84 \%$, protein antara $15-24 \%$, lemak 0,1-2\%, karbohidrat antara 1-3\% dan bahan organik antara 0,8-2\%. Protein ikan juga memiliki daya cerna yang tinggi yaitu hingga mencapai 95\% (Rahayu et al., 1992).Sebagai upaya untuk meningkatkan nilai tambah dari ikan Nila, maka diversifikasi pengolahan perlu dilakukan untuk menciptakan produk baru serta memperpanjang daya awet ikan. Salah satu diversifikasi pengolahan adalah pembuatan dendeng ikan.Komposisi bahan baku dan pencampuran bumbu-bumbu dalam pembuatan produk dendeng akan mempengaruhi kualitas dendeng yang dihasilkan (Purnomo, 1996). Salah satunya yaitu gula merah, gula adalah zat senyawa Organik yang dapat mengikat air, memodifikasi rasa, warna, tekstur dan memperlambat pertumbuhan mikroba (Bailey, 1998). Oleh karena itu, penelitian ini untuk mengetahui karateristik mutu dendeng ikan Nila dengan konsentrasi penambahan gula aren berbeda.

Dendeng merupakan salah satu bentuk hasil olahan pengawetan daging secara tradisional dan telah banyak dilakukan oleh masyarakat Indonesia sejak dulu. Menurut SNI 01-2908-2006 (Badan Standarisasi Nasioanal, 2006), dendeng merupakan produk makanan berbentuk lempengan yang terbuat dari irisan atau gilingan daging segar yang telah diberi bumbu dan dikeringkan. Dendeng memiliki cita rasa yang khas, yaitu manis agak asam dan warna yang gelap akibat kadar gulanya yang cukup tinggi. Kombinasi gula, garam, dan bumbubumbu menimbulkan bau khas pada produk akhir (Purnomo, 1996).

\section{METODE PENELITIAN}

Penelitian ini dilaksanakan di Laboratorium Kimia Hasil Pertanian, Jurusan Teknologi Pertanian, Fakultas Pertanian,
Universitas Sriwijaya. Penelitian ini dilakukan mengunakan Rancangan Acak Lengkap (RAL) dengan satu faktor konsentrasi penambahan gula aren berbeda terdiri dari 4 taraf

perlakuan dan diulang sebanyak tiga kali ulangan yaitu :

1. Dendeng tanpa penambahan gula merah (G0)

2. Dendeng dengan penambahan gula merah $10 \%$ (G1)

3. Dendeng dengan penambahan gula merah $20 \%$ (G2)

4. Dendeng dengan penambahan gula merah $30 \%$ (G3)

Prosedur kerja pengolahan dendeng ikan Nila, yang dimodifikasi dari (Eko, Nurcahaya et al., 2008) dengan tahapan pengolahan dendeng ikan Nila adalah sebagai berikut :

1. Pilih ikan Nila segar kemudian disiangi dan dibersihkan dari sisik dan sirip kemudian ikan Nila dipotong dengan panjang $3 \mathrm{~cm} \mathrm{x}$ lebar $2 \mathrm{~cm}$ x ketebalan $0,5 \mathrm{~cm}$. Selanjutnya dilakukan pencucian dengan air bersih untuk membersihkan ikan dari kotoran ikan Nila siap diolah.

2. Haluskan bumbu berupa gula merah sesuai perlakuan (bb), garam $4 \%$ (bb),

laos 5\% (bb), ketumbar 5\% (bb), bawang merah $2 \%$ (bb), bawang putih $2 \%$ (bb) dan asam $4 \%$ (bb).

3. Campurkan semua bumbu dan diaduk sampai merata selanjutnya balurkan bumbu pada potongan daging ikan Nila selama \pm 2 jam. Keringkan dendeng yang sudah dilumuri bumbu dalam oven dengan suhu $60^{\circ} \mathrm{C}$ selama 20-30 menit, dendeng yang sudah kering kemudian diangkat dan didinginkan.

\section{PARAMETER YANG DIAMATI}

Parameter yang dianalisis pada penelitian ini meliputi: Analisa Fisik, Kimia dan Analisa Sensoris. Analisa Fisik meliputi: Analisa Tekstur, Warna. Analisa Kimia meliputi: Kadar Air, Kadar Abu, Protein, Lemak dan Karbohidrat. Analisa Sensoris yaitu uji hedonik meliputi: Penampakan, Warna, Aroma dan Rasa.

\section{HASIL DAN PEMBAHASAN}

\section{A. KARATERISTIK FISIK}

\section{Tekstur}

Tekstur merupakan suatu faktor mutu dendeng yang penting yang dapat mempengaruhi penerimaan konsumen, karena setiap konsumen menginginkan dendeng yang empuk sesuai yang 
diinginkanya (Lavlinesia, 1996 dalam Zen 2010). Pengukuran tekstur dendeng ikan Nila pada penelitian ini menggunakan alat texture analyzer, dan alat ini memberikaan gaya terhadap produk yang berfungsi untuk mem Berdasarkan hasil uji diperoleh nilai rata-rata tekstur berkisar antara 872,3 gram force (gf) sampai dengan 1190,2 force (gf). Tekstur tertinggi terdapat pada perlakuan G0 (tanpa penambahan gula) sedangkan tekstur terendah terdapat pada perlakuan G3 (penambahan gula $30 \%)$. Hasil analisa keragamanan menunjukan bahwa penambahan konsentrasi gula aren berbeda berpengaruh nyata terhadap nilai tekstur dendeng ikan Nila pada taraf uji 5\%. atahkan produk. Semakin rendah nilai yang dihasilkan maka dendeng semakin empuk.

\section{Warna}

\section{a. Lightness $(\mathrm{L})$}

Nilai lightness merupakan tingkatan warna berdasarkan pencampuran dengan unsur warna putih sebagai unsur warna yang memunculkan kesan terang atau gelap. Nilai koreksi warna lightness berkisar antara $0 \%$ untuk warna paling gelap (hitam) dan $100 \%$ untuk warna paling terang (putih). Hasil pengukuran lightness menunjukan nilai tertinggi terdapat pada perlakuan G0 (tanpa penambahan gula) dengan nilai sebesar $46,27 \%$ sedangkan nilai terendah lightness terdapat pada perlakuan G3 (gula 30\%) 35,33\%.

\section{b. Chroma (C)}

adalah tingkatan warna berdasarkan ketajamannya berfungsi untuk mendefinisikan warna suatu produk cenderung mengkilap atau kusam. Chroma mengikuti persentase yang berkisar dari $0 \%$ sampai $100 \%$. Semakin tinggi nilai Chroma, maka produk tersebut cenderung semakin kusam dan sebaliknya semakin rendah semakin menkilap. Nilai rata-rata chroma dendeng ikan Nila menunjukan bahwa nilai tertinggi terdapat pada perlakuan G3 (gula 30\%) sebesar $6,80 \%$ sedangkan yang terendah terdapat pada perlakuan G0 (tanpa gula) 2,93\% .

\section{c. Нuе (H)}

Nilai hue adalah karateristik warna berdasarkan cahaya yang dipantulkan oleh objek yang merupakan nilai keseluruhan yang didominasi pada suatu produk atau warna utama produk. Hasil pengukuran nilai hue dendeng ikan Nila menunjukan bahwa rata-rata nila hue tertinggi terdapat pada perlakuan G3 (gula 30\%) sebesar 60,30 $\left(^{0}\right)$ sedangkan nilai terendah terdapat pada perlakuan G0 (tanpa gula) 17,07 $\left({ }^{0}\right)$.

\section{B. KARATERISTIK KIMIA}

\section{Kadar air}

Kadar air adalah sejumlah air yang terdapat dalam bahan pangan yang terikat secara fisik maupun kimia dan merupakan komponen penting dalam bahan makanan. Kadar air dalam bahan makanan ikut menentukan daya terima, kesegaran, dan daya tahan bahan itu terhadap kerusakan (Winarno, 1997). Tabel 1, Menunjukan bahwa rata-rata nilai kadar air dendeng ikan Nila berkisar antara 15,56\% sampai $21,32 \%$. Kadar air tertinggi terdapat pada perlakuan G0 (tanpa penambahan gula) sedangkan nilai kadar air terendah terdapat pada perlakuan G3 (penambahan gula 30\%).

Tabel 1. Uji lanjut BNJ penambahan konsentrasi dengan penambahan gula aren berbeda terhadap kadar air dendeng ikan Nila

\begin{tabular}{ccc}
\hline Perlakuan & Rerata $\%$ & BNJ 5 \% $=8,17$ \\
\hline G3 (Penambahan gula 30\%) & 15,56 & $\mathrm{a}$ \\
G2 (penambahan gula 20\%) & 17,75 & $\mathrm{a}$ \\
G1 (Penambahan gula 30\%) & 18,11 & $\mathrm{a}$ \\
G0 (Tanpa penambahan gula) & 21,32 & $\mathrm{~b}$
\end{tabular}

Keterangan : Angka-angka yang diikuti huruf yang tidak sama pada kolom yang berbeda menunjukan perlakuan berbeda nyata $(5 \%)$.

\section{Kadar abu}

Kadar abu tidak selalu equivalen dengan bahan mineral, karena adanya beberapa mineral hilang selama volatisasi atau interaksi antara konstituen (Sulaiman et al., 1995). Gambar 9, menunjukan bahwa rata - rata nilai kadar abu dendeng ikan Nila berkisar antara 3,17\%-4,32\%. Kadar abu tertinggi terdapat pada perlakuan G3 (penambahan gula 30\%). 


\section{Kadar lemak}

Lemak merupakan salah satu kelompok senyawa organik yang terdapat dalam tumbuhan, hewan dan manusia yang sangat berguna bagi kehidupan manusia. Gambar 10 menunjukan bahwa rata-rata nilai kadar lemak dendeng ikan Nila berkisar antara 9,18\% sampai $14,36 \%$. Kadar lemak tertinggi terdapat pada perlakuan G3 (penambahan gula 30\%) sebesar 14,36\% sedangkan nilai kadar lemak terendah pada perlakuan G0 (tanpa penambahan gula) sebesar 9,18 .

\section{Protein}

Protein merupakan suatu zat makanan yang amat penting dalam tubuh bagi setiap sel yang hidup. Selain berfungsi sebagai bahan bakar dalam tubuh juga berfungsi sebagai zat pembangun dan pengatur (Winarno, 1997). Hasil uji lanjut BNJ menunjukan bahwa semua perlakuan berbeda nyata. Dendeng ikan Nila perlakuan G3 (gula 30\%) memiliki kadar protein tertinggi yaitu sebesar 27,67 (\%), sedangkan nilai terendah terdapat pada perlakuan G0 (tanpa gula) yaitu $17,09 \%$.

\section{Karbohidrat}

Karbohidrat mempunyai peranan penting dalam menentukan karateristik bahan makanan, misalnya rasa, warna, tekstur dan lain-lain. Kadar Karbohidrat by difference ditentukan dari hasil pengurangan $100 \%$ dengan kadar air, kadar abu, kadar lemak, dan kadar protein, sehingga kadar karbohidrat bergantung pada faktor penguranganya (Winarno, 1997). Berdasarkan hasil penelitian, kadar karbohidrat by difference berkisar antara 38,04\% sampai dengan 49,24\%. Kadar karbohidrat by difference tertinggi terdapat pada perlakuan G0 (tanpa penambahan gula) sedangkan yang terendah terdapat pada perlakuan G3 (penambahan gula 30\%).

\section{KARATERISTIK SENSORIS}

\section{a. Penampakan}

Karakteristik pertama yang dinilai konsumen suatu produk adalah penampakan, sebelum mengenal atau menyukai sifat mutu organoleptik yang lainnya meskipun tidak menentukan tingkat kesukaan konsumen secara mutlak. Produk dengan bentuk rapi, bagus, utuh pasti lebih disukai konsumen dibandingkan dengan produk yang kurang rapi dan tidak utuh (Soekarto, 1990). Berdasarkan uji hedonik, diketahui bahwa tingkat penerimaan panelis terhadap penampakan dendeng ikan menghasilkan rata-rata nilai penampakan ikan berkisar antara 3,68 sampai 4,04.

\section{b. Aroma}

Aroma merupakan zat volatil yang dilepaskan dari produk yang ada didalam mulut, aroma sering kali disebut sebagai bau dari bahan pangan, serta salah satu faktor yang menentukan suatu makanan dapat diterima oleh konsumen adalah aroma. Aroma makanan juga banyak ditentukan kelezatan makanan tersebut (Winarno, 1997). Berdasarkan hasil uji hedonik, diketahui bahwa tingkat penerimaan panelis terhadap aroma dendeng ikan Nila menghasilkan rata-rata nilai aroma dendeng ikan Nila berkisar anatara 3,44 sampai 4,00 .

\section{c. Warna}

Warna adalah hal yang penting untuk suatu penampilan produk pangan. Warna merupakan hasil respon yang diterima mata dari rangsangan fisik berupa cahaya yang berkaitan dengan indera penglihatan (Soekarto dan Hubeies, 2000). Hasil uji hedonik terhadap warna dendeng ikan Nila menunjukan bahwa nilai rerata tingkat kesukaan berkisar antara 3,32 (tidak suka) sampai dengan 3,92 (suka). Nilai tertinggi terdapat pada perlakuan G3 (gula 30\%) sedangkan terendah terdapat pada perlakuan G0 (tanpa gula).

\section{d. Rasa}

Rasa adalah sesuatu yang diterima oleh lidah. Dalam pengindraan dibagi empat cicipan utama yaitu manis, pahit, asam dan asin serta ada tambahan respon bila dilakukan modifikasi (Kustyatiyah dan Nurjannah, 2005). Hasil uji hedonik terhadap rasa dendeng ikan Nila menunjukan bahwa nilai rerata tingkat kesukaan berkisar antara 3,20 (tidak suka) sampai dengan 4,24 (suka). Nilai tertinggi terdapat pada perlakuan G3 (gula 30\%), sedangkan nilai terendah terdapat pada perlakuan G0 (tanpa gula).

\section{KESIMPULAN}

Berdasarkan hasil penelitian yang diperoleh, maka dapat disimpulkan sebagai berikut:

1. Penambahan gula aren dengan konsentrasi berbeda berpengaruh nyata terhadap tekstur, lightness, chroma, hue, kadar air, kadar abu, kadar lemak, kadar protein dan karbohidrat pada dendeng ikan Nila dan tidak berpengaruh nyata terhadap nilai penampakan.

2. Perlakuan terbaik terdapat pada perlakuan G3 (penambahan gula 30\%) berdasarkan parameter fisik (tekstur 872,03 gf, lightness 46,27, chroma 6,80, hue 60,30, berdasarkan 
parameter kimia (kadar air 15,56\%, kadar abu $4,32 \%$, kadar protein $27,67 \%$, kadar lemak $14,36 \%$ dan karbohidarat $36,00 \%$ ) dan sensoris (penampakan 3,92\%, aroma 4,00\%, warna $3,92 \%$ dan rasa $4,24 \%$ ).

\section{DAFTAR PUSTAKA}

Badan Standarisasi Nasional. 1992. SNI 012908-1992. Dendeng Sapi. Badan Standarisasi Nasional, Jakarta.

Bailey, M.E. 1998. Maillard reaction and meat flavour development. Dalam: F. Shahidi (Ed). Flavour of Meat Product and Seafood. 2nd Ed. Blackie Academic and Profesional, New York.

Heriansyah. 2010. Jenis-Jenis Air Tawar. Penebar Swadaya. Jakarta.

Nurjanah, Abdullah A, Kustiariyah. 2011. Pengetahuan dan Karakteristik Bahan Baku. Institut Pertanian Bogor Press, Bogor.

Purnomo, H. 1996. Dasar-dasar Pengolahan dan Pengawetan Daging. Grasindo, Jakarta

Rahayu. 1992. Rempah-rempah: Komoditi Ekspor Indonesia. Penerbit Sinar Baru, Bandung.

Soekarto, S. T. 1990. Dasar-dasar Pengawasan dan Standardisasi Mutu Pangan. Institut Pertanian Bogor Press, Bogor.

Soekarto, T.S dan M. Hubeis. 2000. Metodologi Penelitian Organoleptik. Institut Pertanian Bogor. Bogor.

Winarno, J. F., R. Gornez, M. A. Carmona. 1997. Water Activity of Spanish Intermediatemoisture Meat Products. Meat sci. 38: 341346.

Winarno, F.G.1997. Kimia Pangan dan Gizi. Gramedia Pustaka Utama. Jakarta. 